\title{
Bacitracin and Rutin Regulate Tissue Factor Production in Inflammatory Monocytes and Acute Myeloid Leukemia Blasts
}

\author{
Lennart Beckmann ${ }^{1,+}{ }^{\dagger}$, Christina Charlotte Rolling ${ }^{1,2,+}$, Minna Voigtländer ${ }^{1}$, Jonathan Mäder ${ }^{1}$, Felix Klingler ${ }^{1}$, \\ Anita Schulenkorf ${ }^{1}$, Carina Lehr ${ }^{1}$, Carsten Bokemeyer ${ }^{1}$, Wolfram Ruf ${ }^{3,4}$ and Florian Langer ${ }^{1, *}$ \\ 1 II. Medizinische Klinik und Poliklinik, Universitätsklinikum Eppendorf, 20246 Hamburg, Germany; \\ l.beckmann@uke.de (L.B.); c.rolling@uke.de (C.C.R.); m.voigtlaender@uke.de (M.V.); \\ 6958528@stud.uke.uni-hamburg.de (J.M.); f.klingler@uke.de (F.K.); a.schulenkorf@uke.de (A.S.); \\ c.lehr@uke.de (C.L.); cbokemeyer@uke.de (C.B.) \\ 2 Department of Medicine, New York University Grossman School of Medicine, New York, NY 10016, USA \\ 3 Centrum für Thrombose und Hämostase, Universitätsmedizin der Johannes Gutenberg-Universität Mainz, \\ 55131 Mainz, Germany; ruf@uni-mainz.de \\ 4 Department of Immunology and Microbiology, The Scripps Research Institute, La Jolla, CA 92037, USA \\ * Correspondence: langer@uke.de; Tel.: +49-40-7410-52453 \\ + Lennart Beckmann and Christina C. Rolling contributed equally to this work.
}

Citation: Beckmann, L.; Rolling, C.C.; Voigtländer, M.; Mäder, J.; Klingler, F.; Schulenkorf, A.; Lehr, C.; Bokemeyer, C.; Ruf, W.; Langer, F. Bacitracin and Rutin Regulate Tissue Factor Production in Inflammatory Monocytes and Acute Myeloid Leukemia Blasts. Cancers 2021, 13, 3941. https://doi.org/10.3390/ cancers13163941

Academic Editor: Godefridus J (Frits) Peters

Received: 30 June 2021

Accepted: 2 August 2021

Published: 4 August 2021

Publisher's Note: MDPI stays neutral with regard to jurisdictional claims in published maps and institutional affiliations.

Copyright: (c) 2021 by the authors. Licensee MDPI, Basel, Switzerland. This article is an open access article distributed under the terms and conditions of the Creative Commons Attribution (CC BY) license (https:/ / creativecommons.org/licenses/by/ $4.0 /)$.
Simple Summary: Aberrant tissue factor (TF) expression by transformed myeloblasts and inflammatory monocytes contributes to coagulation activation in acute myeloid leukemia (AML). TF procoagulant activity (PCA) is regulated by protein disulfide isomerase (PDI), an oxidoreductase with chaperone activity, but its specific role in AML-associated TF biology is unclear. Here, we provide novel mechanistic insights into this interrelation. We show that bacitracin and rutin, two pan-inhibitors of the PDI family, prevent lipopolysaccharide (LPS)-induced monocyte TF production under inflammatory conditions and constitutive TF expression by THP1 cells and AML blasts, thus exerting promising anticoagulant activity. Downregulation of the TF protein was mainly restricted to its non-coagulant, cryptic pool and was at least partially regulated on the mRNA level in LPSstimulated monocytes. Collectively, our study indicates a complex role of thiol isomerases in the regulation of myeloid TF PCA, with the most abundant PDI being a promising therapeutic target in the management of AML-associated coagulopathies.

Abstract: Aberrant expression of tissue factor (TF) by transformed myeloblasts and inflammatory monocytes drives coagulation activation in acute myeloid leukemia (AML). Although regulation of TF procoagulant activity (PCA) involves thiol-disulfide exchange reactions, the specific role of protein disulfide isomerase (PDI) and other thiol isomerases in AML-associated TF biology is unclear. THP1 cells and peripheral blood mononuclear cells (PBMCs) from healthy controls or AML patients were analyzed for thiol isomerase-dependent TF production under various experimental conditions. Total cellular and membrane TF antigen, TF PCA and TF mRNA were analyzed by ELISA, flow cytometry, clotting or Xa generation assay and qPCR, respectively. PBMCs and THP1 cells showed significant insulin reductase activity, which was inhibited by bacitracin or rutin. Co-incubation with these thiol isomerase inhibitors prevented LPS-induced TF production by CD14-positive monocytes and constitutive TF expression by THP1 cells and AML blasts. Downregulation of the TF antigen was mainly restricted to the cryptic pool of TF, efficiently preventing phosphatidylserine-dependent TF activation by daunorubicin, and at least partially regulated on the mRNA level in LPS-stimulated monocytes. Our study thus delineates a complex role of thiol isomerases in the regulation of myeloid TF PCA, with PDI being a promising therapeutic target in the management of AMLassociated coagulopathies.

Keywords: tissue factor; protein disulfide isomerase; acute myeloid leukemia; coagulation; inflammation; rutin; monocytes 


\section{Introduction}

Acquired coagulation disorders are a common complication in patients with acute myeloid leukemia (AML). Although particularly frequent in acute promyelocytic leukemia (APL), clotting abnormalities also occur in other AML subtypes, mainly of (myelo-) monocytic differentiation, and can manifest with both hemorrhagic and thromboembolic events [1,2]. While bleeding occurs in up to $60 \%$ of AML patients at initial presentation [3], up to $10 \%$ develop venous thromboembolism (VTE) [4-7]. Bleeding in AML patients is caused by disease- or treatment-related thrombocytopenia and complex systemic coagulopathies, such as excessive fibrinolysis, disseminated intravascular coagulation (DIC), or non-specific proteolysis [1,2]. In this regard, aberrant expression of tissue factor (TF) by transformed myeloblasts or pro-inflammatory monocytes significantly contributes to the procoagulant state $[1,2,8,9]$.

TF is a 42-kDa transmembrane protein and the principal initiator of the coagulation protease cascade through complex formation with (activated) factor VII (FVII/FVIIa) [10]. TF is also involved in cell signaling via stimulation of protease-activated receptors (PARs), thus driving inflammation, angiogenesis and cancer progression [10,11].

Under physiological conditions, TF is mainly expressed on perivascular cells. However, TF can also be found within the vasculature on endothelial cells, leukocytes and platelets, where it is induced by pro-inflammatory stimuli, such as bacterial lipopolysaccharide (LPS), tumor necrosis factor $\alpha(\mathrm{TNF} \alpha)$ or interleukin 6 (IL-6), and oxidative stress $[10,12]$. In addition, TF is constitutively expressed by many cancer cells as a result of activation or inactivation of oncogenes and tumor suppressor genes, respectively [13,14]. In line with these observations, TF is frequently found on transformed myeloblasts $[8,15-17]$. However, AML is also characterized by a highly pro-inflammatory state with increased production of various inflammatory cytokines, such as IL-1 $\beta$, IL-6, or TNF $\alpha[2,18]$. These cytokines drive disease progression in the hematopoietic stem cell niche, but also induce TF expression in non-transformed monocytes $[2,9,18]$.

On cell membranes, the vast majority of TF resides in a non-coagulant, functionally inactive state [19]. This cryptic TF can be rapidly converted into its procoagulant isoform by different, synergistic mechanisms. These include alterations of the membrane phospholipid composition with increased exposure of negatively charged phosphatidylserine (PS) and thiol-disulfide exchange reactions, which eventually result in oxidation of an allosteric disulfide bond within the TF extracellular domain and which are mediated by thiol isomerases, such as protein disulfide isomerase (PDI) [19-21].

PDI is predominantly expressed in the endoplasmic reticulum (ER) of eukaryotic cells, but it is also retained on cell surfaces or released into the vasculature upon endothelial or platelet activation [22-25]. While PDI mediates protein folding in the ER, intravascular PDI and several other thiol isomerases, such as endoplasmic reticulum protein 5 (ERp5), ERp57, ERp72, or thioredoxin, participate in thrombus formation by modulating platelet adhesion and aggregation, activation of monocyte TF and fibrin formation [24-33]. Although the precise mechanisms remain incompletely understood, inhibition of thiol isomerase reductase activity was associated with promising anti-thrombotic activity in several preclinical studies [25-28,32,34]. Moreover, daily administration of the PDI inhibitor isoquercetin significantly reduced plasma levels of D-dimer and soluble P-selectin as well as plateletassociated thrombin generation in patients with solid cancers [35]. These findings point to a therapeutic potential of thiol isomerase inhibition in the management of cancer-associated thrombosis (CAT).

Since PDI has been found in relevant concentrations in AML blasts [36], we investigated whether cellular TF procoagulant function is regulated by thiol isomerases in this hematological malignancy. 


\section{Materials and Methods}

\subsection{Materials}

The following reagents were obtained from commercial sources: bacitracin (TOKU-E, Bellingham, WA, USA), quercetin-3-rutinoside (rutin), daunorubicin (DNR), lipopolysaccharide (LPS, Escherichia coli serotype O111:B4) (all from Sigma Aldrich, St. Louis, MO, USA), antithymocyte globulin (ATG) (Fresenius, Bad Homburg, Germany), normal human plasma (NHP) (HemosIL ${ }^{\circledR}$; Instrumentation Laboratory, Kirchheim, Germany), lipidated recombinant human full-length tissue factor (Innovin ${ }^{\circledR}$; Siemens Healthcare, Erlangen, Germany), plasma-derived human coagulation factor X (FX) (Merck Millipore, Darmstadt, Germany), recombinant human FVIIa (NovoSeven ${ }^{\circledR}$; Novo Nordisk, Bagsvaerd, Denmark), FXa chromogenic substrate BIOPHEN ${ }^{\circledR}$ CS-11(65) (Hyphen-BioMed, Neuville-sur-Oise, France), inhibitory monoclonal antibodies against human TF (no. 4509; Sekisui Diagnostics, Burlington, MA, USA) and PDI (RL-90; Novus Biologicals, Littleton, CO, USA), unconjugated mouse $I_{g} G_{1}$ and $I_{2} G_{2 a}$ isotype controls (both from R\&D Systems, Minneapolis, MN, USA), polyclonal rabbit IgG (Sigma Aldrich), fluorescein isothiocyanate (FITC)-conjugated monoclonal antibody against CD14 (clone RMO52; Beckman Coulter, Krefeld, Germany), TF (clone VD8; Sekisui Diagnostics) and isotype-matched IgG $_{1}$ control (clone 679.1Mc7; Beckman Coulter), phycoerythrin (PE)-conjugated monoclonal antibodies against TF (clone HTF-1; BD Biosciences, Franklin Lakes, NJ, USA) and isotype-matched IgG $_{1}$ control (clone 679.1Mc7; Beckman Coulter), DyLight ${ }^{\mathrm{TM}}$ 488-conjugated monoclonal antibody against PDI (clone 1D3) and isotype-matched $\mathrm{IgG}_{1}$ control (clone MOPC-21; both from Enzo Life Sciences, Farmingdale, NY, USA) and PE-conjugated annexin V (BD Biosciences).

\subsection{Methods}

\subsubsection{Cell Lines and Cultures}

THP1 and U937 cells were from the DSMZ, German Collection of Microorganisms and Cell Cultures GmbH (Braunschweig, Germany), and maintained in an RPMI culture medium supplemented with $10 \%$ heat-inactivated fetal calf serum (FCS) at $37{ }^{\circ} \mathrm{C}$ and $5 \% \mathrm{CO}_{2}$.

\subsubsection{Collection of Blood Samples}

Venous blood was drawn from an antecubital vein under no or minimal stasis into plastic tubes prefilled with 3.2\% $(0.109 \mathrm{M})$ sodium citrate from AML patients or healthy controls.

\subsubsection{Isolation and Stimulation of Peripheral Blood Mononuclear Cells (PBMCs)}

PBMCs were isolated from citrate-anticoagulated whole blood by density gradient centrifugation. When indicated, monocytes were subsequently purified from PBMCs by magnetic-activated cell sorting using CD14 MicroBeads (Miltenyi Biotec GmbH, Bergisch Gladbach, Germany) on an MS column. Isolated PBMCs or CD14-positive monocytes were maintained in suspension culture in RPMI medium supplemented with $20 \%$ FCS at $2 \times 10^{6} / \mathrm{mL}$. In typical experiments, PBMCs or monocytes were treated with phosphatebuffered saline (PBS, control) or LPS $(100 \mathrm{ng} / \mathrm{mL})$ in the presence or absence of thiol isomerase inhibitors, rutin $(100 \mu \mathrm{M})$ or bacitracin $(5 \mathrm{mM})$, for $4 \mathrm{~h}$ at $37^{\circ} \mathrm{C}$. Following stimulation, cells were washed, resuspended in PBS and analyzed for their procoagulant response by various techniques. For quantitative PCR (qPCR) analysis, a shorter LPS incubation period of $2 \mathrm{~h}$ was chosen.

\subsubsection{LPS Stimulation of Whole Blood}

Citrate-anticoagulated whole blood was stimulated with PBS (control) or LPS $(10 \mu \mathrm{g} / \mathrm{mL})$ in the presence or absence of rutin $(100 \mu \mathrm{M})$ for $4 \mathrm{~h}$ at $37^{\circ} \mathrm{C}$. The LPS concentration of $10 \mu \mathrm{g} / \mathrm{mL}$ was based on previous findings of our group and a report analyzing the (pre-) analytical variables affecting the measurement of plasma-derived microvesicleassociated TF activity [37,38]. Following stimulation, whole blood was immediately assessed for monocyte TF antigen by flow cytometry or centrifuged twice at $2050 \times g$ for 
$10 \mathrm{~min}$ at room temperature (RT) to obtain platelet-poor plasma (PPP). PPP was aliquoted, snap-frozen in liquid nitrogen and stored at $-80^{\circ} \mathrm{C}$ until isolation of microvesicles (MVs). When indicated, PBMCs were isolated from stimulated whole blood by density gradient centrifugation as described before.

\subsubsection{Cell Culture Experiments}

In most experiments, THP1 cells or freshly isolated myeloblasts from patients with newly diagnosed AML were used to investigate the effect of thiol isomerase inhibition under various experimental conditions. Typically, cells were suspended in fresh RPMI medium supplemented with $20 \%$ FCS at $2 \times 10^{6} / \mathrm{mL}$ and incubated in the presence or absence of thiol isomerase inhibitors, rutin $(100 \mu \mathrm{M})$ or bacitracin $(5 \mathrm{mM})$, for $24 \mathrm{~h}$ at $37^{\circ} \mathrm{C}$. Cells were washed and resuspended in PBS for further analysis. When indicated, washed cells were loaded with $100 \mu \mathrm{g} / \mathrm{mL}$ of polyclonal rabbit IgG or ATG, or physically disrupted by repeated freeze-thawing to activate cryptic TF. In other experiments, cells were exposed for $24 \mathrm{~h}$ to $1 \mu \mathrm{M}$ daunorubicin (DNR) in the presence or absence of rutin or bacitracin. Short-term incubation of cells for $30 \mathrm{~min}$ were carried out in PBS.

\subsubsection{Single-Stage Clotting Assay}

Cellular procoagulant activity (PCA) was measured by single-stage clotting assay using a KC10 coagulation instrument (Amelung, Lemgo, Germany). Briefly, $100 \mu \mathrm{L}$ of cell suspension $\left(2 \times 10^{6} / \mathrm{mL}\right.$ ) was mixed 1:1 (vol:vol) with NHP for 2 min at $37^{\circ} \mathrm{C}$ before the addition of $50 \mu \mathrm{L}$ of $\mathrm{CaCl}_{2}(25 \mathrm{mM})$. Times until fibrin clot formation were recorded and mean clotting times were converted into arbitrary activity units (AU) in reference to a standard curve obtained by serial dilutions (1:10-1:100,000) of Innovin ${ }^{\mathrm{TM}}$. All assays were performed in duplicates, except for experiments using patient-derived myeloblasts, which were performed in triplicates. An inhibitory TF antibody $(20 \mu \mathrm{g} / \mathrm{mL})$ was used to demonstrate TF specificity.

\subsubsection{Flow Cytometry}

Flow cytometry was used to measure the expression of PDI, TF and phosphatidylserine (PS) on non-permeabilized cells. Monocytes were identified in whole blood or PBMC preparations by CD14 staining. In such experiments, TF was measured by double-color flow cytometry using the function blocking HTF-1 monoclonal antibody, which specifically recognizes TF on LPS-stimulated monocytes [39,40]. In cell line experiments, single-color flow cytometry was carried out using the FITC-labeled VD8 monoclonal TF antibody. In brief, $200 \mu \mathrm{L}$ of citrate-anticoagulated whole blood or $4 \times 10^{5}$ cells were stained for 20 min at RT in the dark with conjugated antibodies against TF or PDI. For PS exposure, a fluorophore-labeled annexin V derivative was used according to the manufacturer's instructions. Following incubation and lysis of erythrocytes in whole blood samples, cells were washed once with PBS and analyzed on a FACSCalibur ${ }^{\mathrm{TM}}$ (BD Biosciences). Results were expressed as the proportion (\%) of positive cells, which was obtained by subtracting the non-specific background measured in the presence of control IgG from the signal received in the presence of specific antibodies.

\subsubsection{TF ELISA}

Cell lysates from THP-1 cells and PBMCs were prepared by $1 \%$ Triton $\mathrm{X}-100$ protein extraction and total cellular TF antigen was measured using the Quantikine ${ }^{\circledR}$ ELISA kit (R\&D Systems) according to the manufacturer's instructions.

\subsubsection{Thiol Isomerase Activity Assay}

Cell surface thiol isomerase activity was assessed on THP1 cells, PBMCs and leukemic blasts by measuring its reductase activity using a fluorescence-based insulin reduction assay (ProteoStat PDI Assay Kit; Enzo Life Sciences). 


\subsubsection{FXa Generation Assay}

Following LPS stimulation, MVs were isolated from PPP or cell culture supernatants by double high-speed centrifugation at $16,100 \times g$ for $30 \mathrm{~min}$ at RT. Pelleted MVs were resuspended in PBS to one-third of their initial sample volume and analyzed for TF-specific activity by a two-stage chromogenic FXa generation assay, as previously described [41].

\subsubsection{Real-Time Quantitative PCR (qPCR)}

Following stimulation of whole blood or purified PBMCs for $2 \mathrm{~h}$, PBMCs were analyzed for relative changes in TF mRNA levels by real-time qPCR. To this end, stimulated cells were pelleted at $2000 \times g$ for $10 \mathrm{~min}$ at $4{ }^{\circ} \mathrm{C}$ and stored at $-80^{\circ} \mathrm{C}$. The housekeeping gene GAPDH served as reference gene. Total RNA was extracted from $4 \times 10^{6}$ PBMCs with the PureLink ${ }^{\mathrm{TM}}$ RNA Mini Kit (Life Technologies ${ }^{\mathrm{TM}}$, Carlsbad, CA, USA). Following reverse transcription into cDNA with the Maxima First Strand cDNA Synthesis kit for RT-qPCR (ThermoFisher Scientific, Waltham, MA, USA), quantitative PCR was performed in triplicates with the SYBR ${ }^{\circledR}$ Premix Ex Taq ${ }^{\mathrm{TM}}$ II Kit (TaKaRa Bio, Kusatsu, Japan) on a LightCycler ${ }^{\circledR} 96$ system (Roche, Basel, Switzerland). A total of 40 PCR cycles were carried out, each consisting of denaturation at $95^{\circ} \mathrm{C}$ for $15 \mathrm{~s}$, annealing at $58{ }^{\circ} \mathrm{C}$ for $5 \mathrm{~s}$ and extension at $72{ }^{\circ} \mathrm{C}$ for $26 \mathrm{~s}$. Primer sequences for TF and GAPDH were as previously described [42]. Self-dimer formation of the primer pairs was initially excluded by gel electrophoresis (data not shown). Relative changes in TF mRNA levels were analyzed by the modified mathematical approach reported by Pfaffl [43].

\subsubsection{Statistical Analysis}

All experiments were repeated at least three times and results are presented as mean \pm standard deviation (SD). All data were normally distributed using the ShapiroWilk-test. When two conditions were compared, data were analyzed with the Student's $t$-test for paired observations. For multiple comparisons, ANOVA with Tukey's post-hoc test was carried out. Differences with a $p$-value of $<0.05$ were considered statistically significant.

\section{Results}

\subsection{Thiol Isomerases Regulate Monocyte TF PCA under Pro-Inflammatory Conditions}

TF-mediated coagulation abnormalities are particularly frequent in AML subtypes with (myelo-) monocytic differentiation [17]. In addition, non-transformed monocytes/ macrophages participate in the generation of a hypercoagulable state. This is done through the production of TF upon stimulation by various cytokines and endotoxins released, e.g., during bacterial infections or as a result from pro-inflammatory signaling pathways within the bone marrow microenvironment [2,9]. Previous studies have shown that thiol-disulfide exchange reactions are critically involved in the regulation of TF procoagulant activity (PCA) in monocytes/macrophages $[25,26,44,45]$. The exact mechanisms, by which PDI and other thiol isomerases control cellular TF activity under pro-inflammatory conditions, however, remain incompletely understood. We therefore performed initial experiments to gain deeper insights into this issue.

Peripheral blood mononuclear cells (PBMCs) from healthy volunteers were stimulated with lipopolysaccharide (LPS) for $4 \mathrm{~h}$ to induce TF-specific PCA (Figure 1A). Freshly isolated PBMCs expressed robust insulin reductase activity, which was similar to that of purified PDI (Figure 1B). Bacitracin, a more non-specific extracellular thiol isomerase inhibitor, dose-dependently inhibited recombinant PDI (Figure S1) and also interfered with PBMC-associated insulin reductase activity (Figure 1B).

To further elucidate the role of thiol isomerases in the regulation of monocyte TF PCA under pro-inflammatory conditions, LPS stimulation of PBMCs was carried out in the presence or absence of bacitracin. While co-incubation with bacitracin had no effect on controls (Figure 1C), it reduced the PCA of LPS-stimulated PBMCs in a concentration-dependent manner (Figure $1 \mathrm{C}$ and Figure S2A). In addition, bacitracin prevented TF antigen expression on CD14-positive monocytes (Figure 1D). Importantly, bacitracin did not amplify phos- 
phatidylserine (PS) membrane exposure on LPS-treated monocytes (Figure S2B), indicating that regulation of TF production by bacitracin did not involve cytotoxic effects.

Taken together, these findings indicate that inhibition of cell-surface thiol isomerase activity by bacitracin inhibits LPS-induced monocyte TF production.
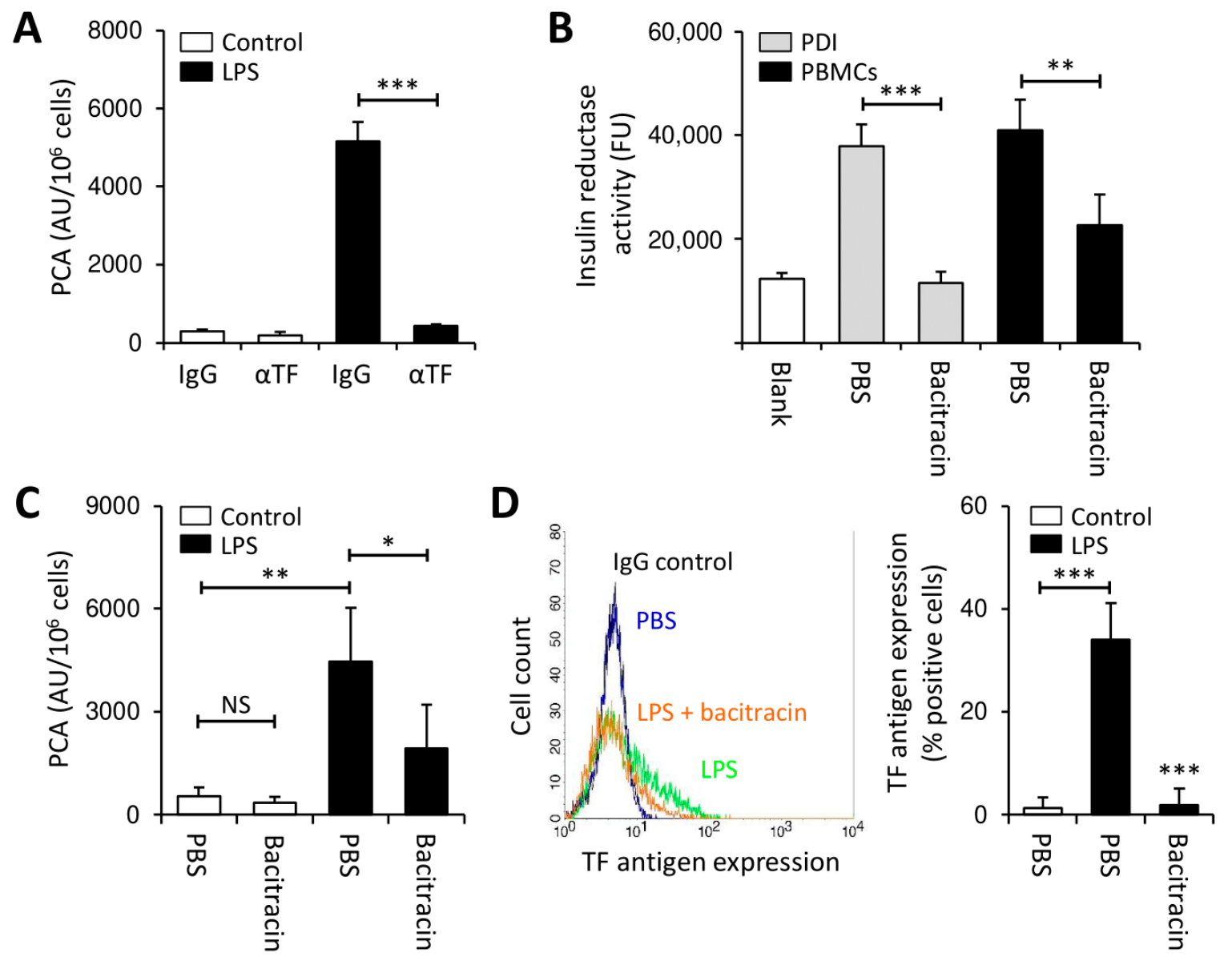

Figure 1. Thiol isomerases regulate lipopolysaccharide (LPS)-induced tissue factor (TF) expression in peripheral blood mononuclear cells (PBMCs). (A) PBMCs $\left(2 \times 10^{6} / \mathrm{mL}\right)$ were incubated with LPS $(100 \mathrm{ng} / \mathrm{mL})$ or PBS (control) for $4 \mathrm{~h}$ at $37^{\circ} \mathrm{C}$ and subsequently analyzed for procoagulant activity (PCA) by single-stage clotting assay (mean $\pm \mathrm{SD}, n=6$ ). An inhibitory TF antibody $(\alpha \mathrm{TF})$ was added in comparison to IgG isotype control to demonstrate TF specificity. (B) Cell-associated thiol isomerase activity was measured on freshly isolated PBMCs following incubation with PBS or bacitracin (5 mM) for $30 \mathrm{~min}$ using a fluorogenic insulin reductase activity assay (mean $\pm \mathrm{SD}, n=3$ ). Recombinant human PDI, as provided by the manufacturer, served as positive control. (C,D) Incubation of PBMCs with LPS or PBS for $4 \mathrm{~h}$ at $37^{\circ} \mathrm{C}$ was carried out in the presence or absence of $5 \mathrm{mM}$ bacitracin. Cells were then assessed for PCA by single-stage clotting assay $(\mathrm{mean} \pm \mathrm{SD}, n=6)$ or monocyte TF antigen expression by flow cytometry (mean $\pm \mathrm{SD}, n=5$ ). $p$-values are according to Tukey's post-hoc test (NS, not significant; $\left.{ }^{*}, p<0.05 ;{ }^{* *}, p<0.01 ;{ }^{* * *}, p<0.001\right)$.

\subsection{Rutin Prevents LPS-Induced TF Production by PBMCs}

In contrast to bacitracin, quercetin-3-rutinoside (rutin) is a more specific, reversible PDI inhibitor [28,46]. Consistently, rutin potently inhibited PDI insulin reductase activity at saturating concentrations of $>50 \mu \mathrm{M}$ (Figure S3). Similar to bacitracin, co-incubation with rutin had no effect on controls (Figure S4A), but significantly inhibited LPS-induced expression of TF PCA in PBMCs (Figure 2A) and of TF antigen in monocytes (Figure 2B). The inhibitory effect of rutin was concentration- and time-dependent (Figure S4B,C) and not explainable by increased cytotoxicity (Figure S4D). Co-incubation with rutin also significantly reduced total cellular TF antigen in LPS-treated PBMCs (Figure 2C), favoring decreased TF synthesis or increased TF shedding on microvesicles (MVs) over TF internalization as the 
underlying mechanism. To further investigate this issue, we analyzed cellular TF mRNA and MV-associated TF PCA. Both TF mRNA (Figure 2D) and MV TF PCA (Figure 2E) were significantly reduced upon co-incubation of PBMCs with LPS and rutin. Of note, no TF antigen was detected in MV-depleted cell culture supernatants (data not shown), further arguing against increased TF shedding as the underlying mechanism.
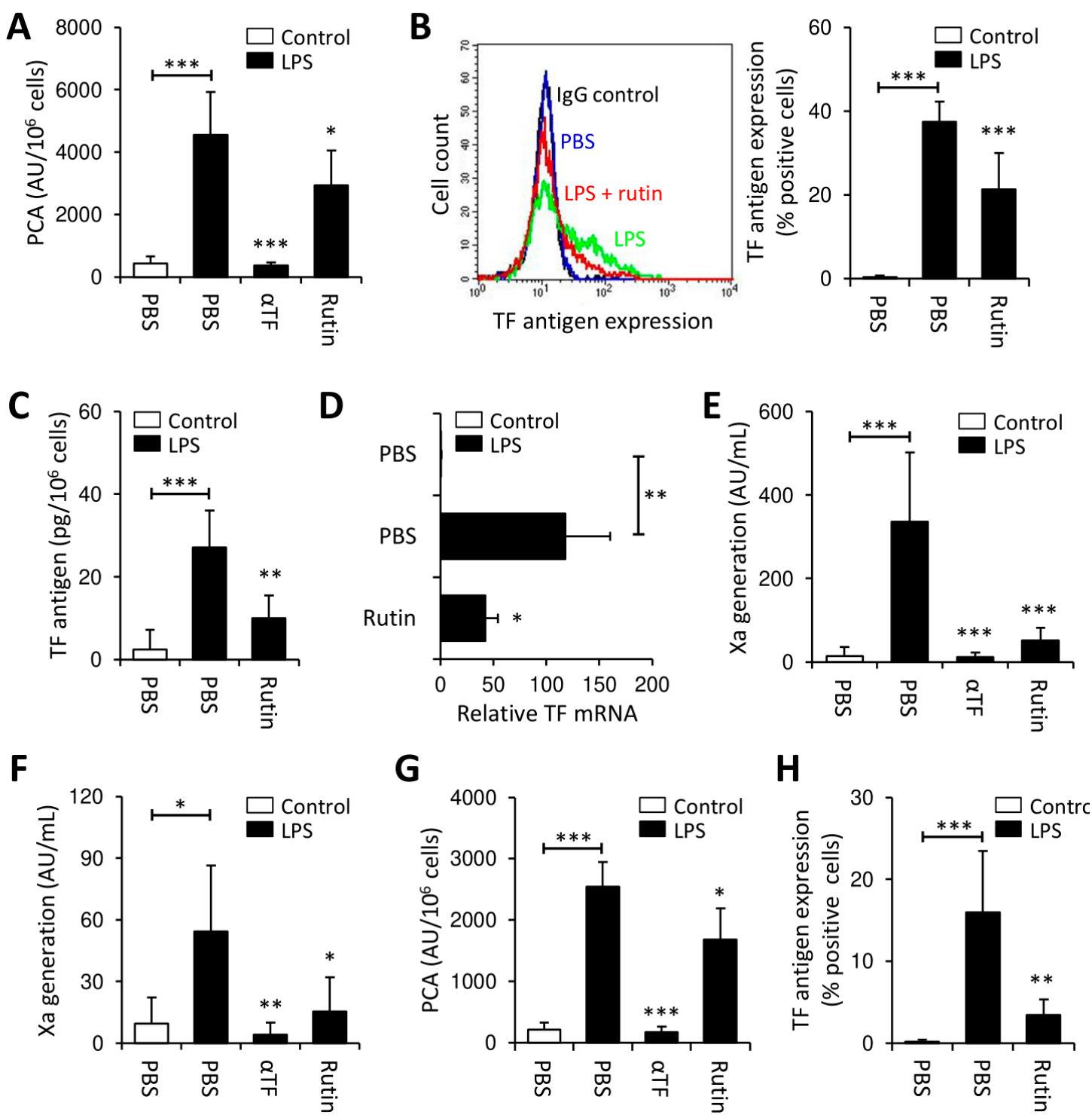

Figure 2. Rutin prevents LPS-induced TF production in PBMCs. (A-E) PBMCs were stimulated with LPS (100 ng/mL) in the presence or absence of the thiol isomerase inhibitor rutin $(100 \mu \mathrm{M})$ for 2 or $4 \mathrm{~h}$ at $37^{\circ} \mathrm{C}$ and subsequently analyzed for (A) TF PCA by single-stage clotting assay (mean $\pm \mathrm{SD}, n=13$ ), (B) monocyte TF antigen by flow cytometry (mean $\pm \mathrm{SD}$, $n=10$ ), (C) total cellular TF antigen by ELISA (mean $\pm \mathrm{SD}, n=6$ ), (D) TF mRNA by quantitative RT PCR (mean \pm SD, $n=5$ ) and (E) release of microvesicle-associated TF PCA by Xa generation assay (mean $\pm \mathrm{SD}, n=11$ ). (F,G) Instead of PBMCs, citrate-anticoagulated whole blood was stimulated with LPS $(10 \mu \mathrm{g} / \mathrm{mL})$ or PBS in the presence or absence of rutin $(100 \mu \mathrm{M})$ for $4 \mathrm{~h}$ at $37^{\circ} \mathrm{C}$. (F) Microvesicles were isolated from platelet-poor plasma by double high-speed centrifugation and analyzed for TF PCA by chromogenic Xa generation assay (mean $\pm S D, n=8)$. (G) PBMCs were isolated by density gradient centrifugation and analyzed for PCA by single-stage clotting assay (mean $\pm \mathrm{SD}, n=5)$. (H) TF antigen expression on CD14-positive monocytes was measured by flow cytometry (mean $\pm \mathrm{SD}, n=8$ ). A representative histogram is shown in the Supplementary Materials (Figure S5A). $p$-values are according to Tukey's post-hoc test $\left({ }^{*}, p<0.05 ;{ }^{* *}, p<0.01 ;{ }^{* * *}, p<0.001\right)$. 
Collectively, these data indicate that prevention of LPS-induced monocyte TF production by rutin involves decreased transcription of the $F 3$ gene or decreased stability of the TF mRNA.

Erythrocytes and platelets also show significant PDI surface expression [47,48]. To investigate whether other blood cells interfere with thiol isomerase-mediated regulation of monocyte TF, whole blood was stimulated with LPS in the presence or absence of rutin. Similar to previous findings, rutin significantly decreased LPS-induced release of MV TF PCA (Figure 2F). Moreover, when PBMCs were isolated from LPS-stimulated whole blood, cellular TF PCA (Figure 2G), TF antigen, as analyzed by flow cytometry (Figure 2H and Figure S5A) or ELISA (Figure S5B), and TF mRNA (Figure S5C) were significantly reduced upon co-incubation with rutin.

Thus, inhibition of thiol isomerase reductase activity by rutin prevents monocyte TF production under pro-inflammatory conditions.

\subsection{Rutin and Bacitracin Regulate Endogenous TF Expression in Monocytic Cells}

We next asked whether thiol isomerases regulate monocyte TF production in the absence of strong pro-inflammatory stimuli, such as LPS. To this end, CD14-positive monocytes were isolated from PBMCs and maintained in suspension culture for $24 \mathrm{~h}$, which resulted in the detection of cell-surface TF antigen by flow cytometry (Figure 3A,B). Consistent with our previous findings, endogenous TF expression was markedly reduced upon co-culture of monocytes with rutin or bacitracin (Figure 3A,B).

In AML, aberrant gene expression drives TF production by transformed myeloblasts $[13,14]$. We thus investigated whether thiol isomerases also regulated constitutive TF expression in the monocytic leukemia cell line, THP1. Similar to freshly isolated PBMCs, THP1 cells showed increased insulin reductase activity, which was inhibited by rutin (Figure S6), thus suggesting the presence of cell surface PDI activity. Constitutive TF expression by THP1 cells was confirmed by flow cytometry (Figure S7A) and clotting assay (Figure S7B). As previously reported [44], most of the TF on unperturbed THP1 cells resided in a functionally cryptic, inactive state. Following incubation of THP1 cells with rutin or bacitracin for $24 \mathrm{~h}$, the TF antigen, as analyzed by flow cytometry (Figure 3C,D) or ELISA (Figure 3E), was significantly reduced, with bacitracin showing a more prominent effect than rutin in flow cytometry studies. Neither short-term (30 $\mathrm{min})$ nor long-term $(24 \mathrm{~h})$ treatment with rutin affected TF PCA on intact THP1 cells (Figure S7C,D), suggesting that TF downregulation by rutin was mainly restricted to the cryptic pool of TF. Similar to TF, the PDI antigen was downregulated from the surface of THP1 cells by overnight culture with rutin or bacitracin (Figure 3F,G). Consistent with this observation, insulin reductase activity on washed THP1 cells was significantly reduced by rutin treatment for $24 \mathrm{~h}$ (Figure $3 \mathrm{H})$.

Taken together, these data indicate that thiol isomerases regulate TF production in monocytic cells in the absence of strong pro-inflammatory stimuli. Moreover, inhibition of thiol isomerase reductase activity is associated with concomitant downregulation of TF and PDI from the surface of THP1 cells.

\subsection{Rutin Prevents TF Activation on THP1 Cells through Downregulation of Cryptic TF Expression}

To explore the functional consequences of our previous observations on TF and PDI, THP1 cells were incubated with rutin for $24 \mathrm{~h}$, washed and then treated with antithymocyte globulin (ATG), which rapidly activates cryptic TF on monocytic cells in a PDI- and complement-dependent manner [44]. Rutin significantly decreased ATG-mediated TF activation on THP1 cells (Figure 4A), a finding consistent with a reduction in the activatable cryptic pool of cell surface-expressed TF. 
A

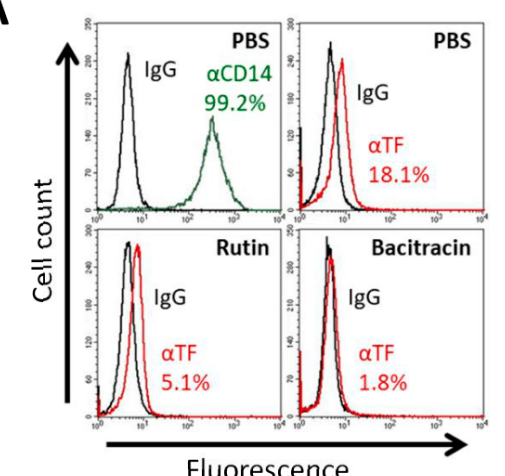

B

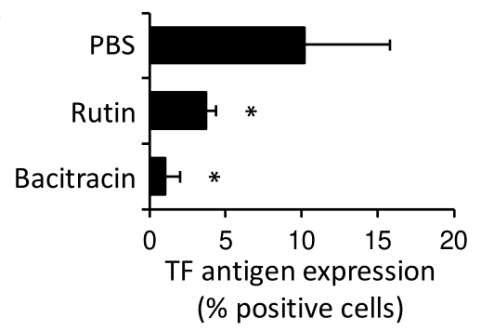

C
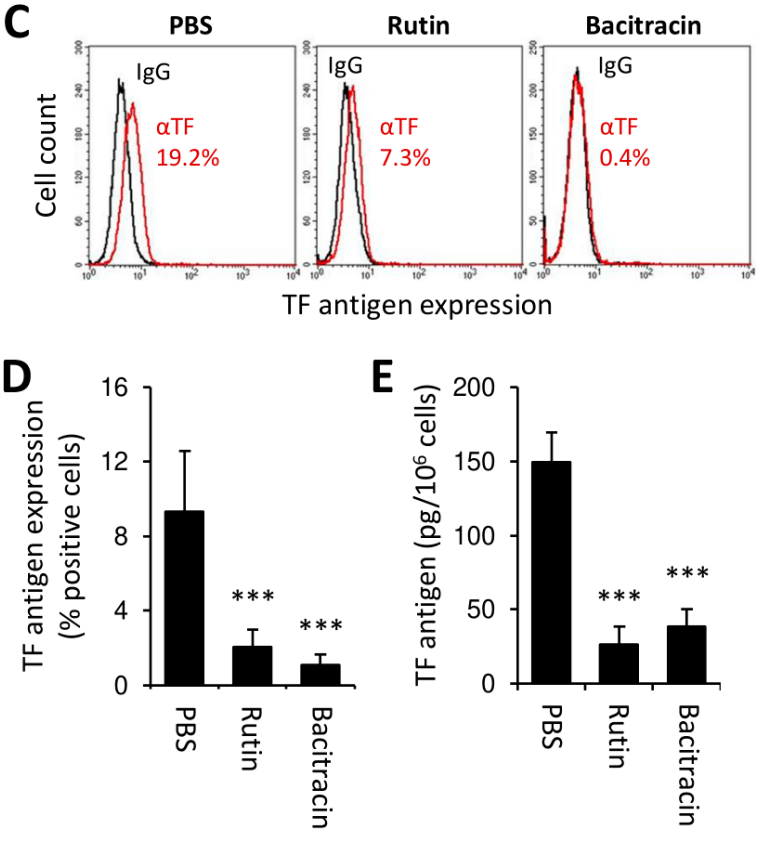

$\mathbf{F}$

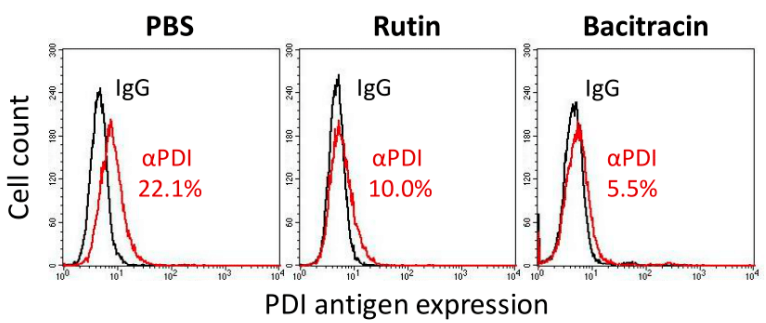

PDI antigen expression
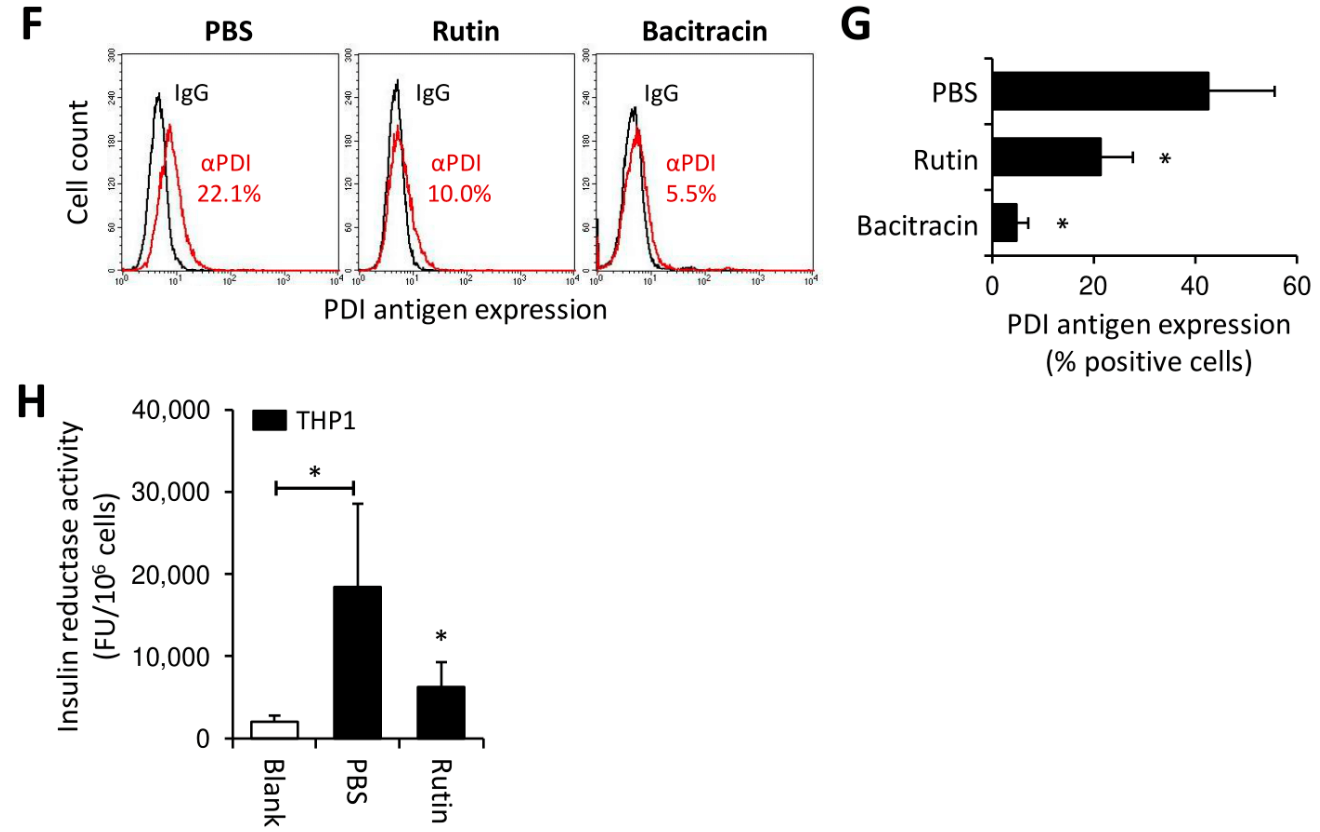

Figure 3. Rutin and bacitracin downregulate PDI and TF in monocytes and THP1 cells. (A,B) CD14-positive monocytes were isolated from PBMCs and maintained in suspension culture for $24 \mathrm{~h}$ at $37^{\circ} \mathrm{C}$ in the presence of PBS (control), rutin $(100 \mu \mathrm{M})$ or bacitracin $(5 \mathrm{mM})$. Cells were subsequently analyzed for TF antigen by flow cytometry $(\mathrm{mean} \pm \mathrm{SD}, n=4)$. $(\mathrm{C}-\mathrm{H})$ THP1 cells were incubated with PBS, rutin $(100 \mu \mathrm{M})$ or bacitracin $(5 \mathrm{mM})$ for $24 \mathrm{~h}$ at $37^{\circ} \mathrm{C}$, washed and analyzed for TF antigen by flow cytometry (mean $\pm \mathrm{SD}, n=11)(\mathbf{C}, \mathbf{D})$, total cellular TF antigen by ELISA (mean $\pm \mathrm{SD}, n=3)(\mathbf{E})$ and for PDI antigen by flow cytometry (mean $\pm \mathrm{SD}, n=3)(\mathrm{F}, \mathrm{G})$. In addition, rutin-treated THP1 cells were assessed for insulin reductase activity (mean $\pm \mathrm{SD}, n=6)(\mathbf{H})$. Representative histograms are shown in panels $(\mathbf{A}, \mathbf{C}, \mathbf{F})$. Corresponding summary statistics are shown in panels $(\mathbf{B}, \mathbf{D})$ and $(\mathbf{G}) . p$-values are according to Tukey's post-hoc test $\left.{ }^{*}, p<0.05 ;{ }^{* * *}, p<0.001\right)$.

Cytotoxic agents activate cellular TF through induction of apoptosis/necrosis, which increases the availability of PS on the outer membrane leaflet [42,49]. THP1 cells were treated with daunorubicin (DNR) in the presence or absence of rutin or bacitracin for $24 \mathrm{~h}$. As expected, DNR significantly enhanced TF-dependent PCA of THP1 cells (Figure 4B,C and Figure S7B) and increased PS membrane exposure (Figure 4D). While both thiol isomerase inhibitors did not affect the PCA of controls, co-incubation with 
rutin or bacitracin dose-dependently prevented DNR-induced TF activation (Figure 4B,C). Importantly, antithrombotic effects of thiol isomerase inhibition could not be explained by prevention of apoptosis/necrosis, as PS exposure on rutin-treated was similar to that on buffer-treated THP1 cells (Figure 4D). To further support a role of PDI in the regulation of TF PCA under these experimental conditions, THP1 cells were treated with DNR in the presence or absence of the function-blocking PDI antibody, RL90. RL90, but not an isotype control, significantly inhibited DNR-mediated cellular TF activation (Figure S8A). Inhibition of DNR-induced TF activation by bacitracin was confirmed using the monocytic leukemia cell line, U937 (Figure S8B).
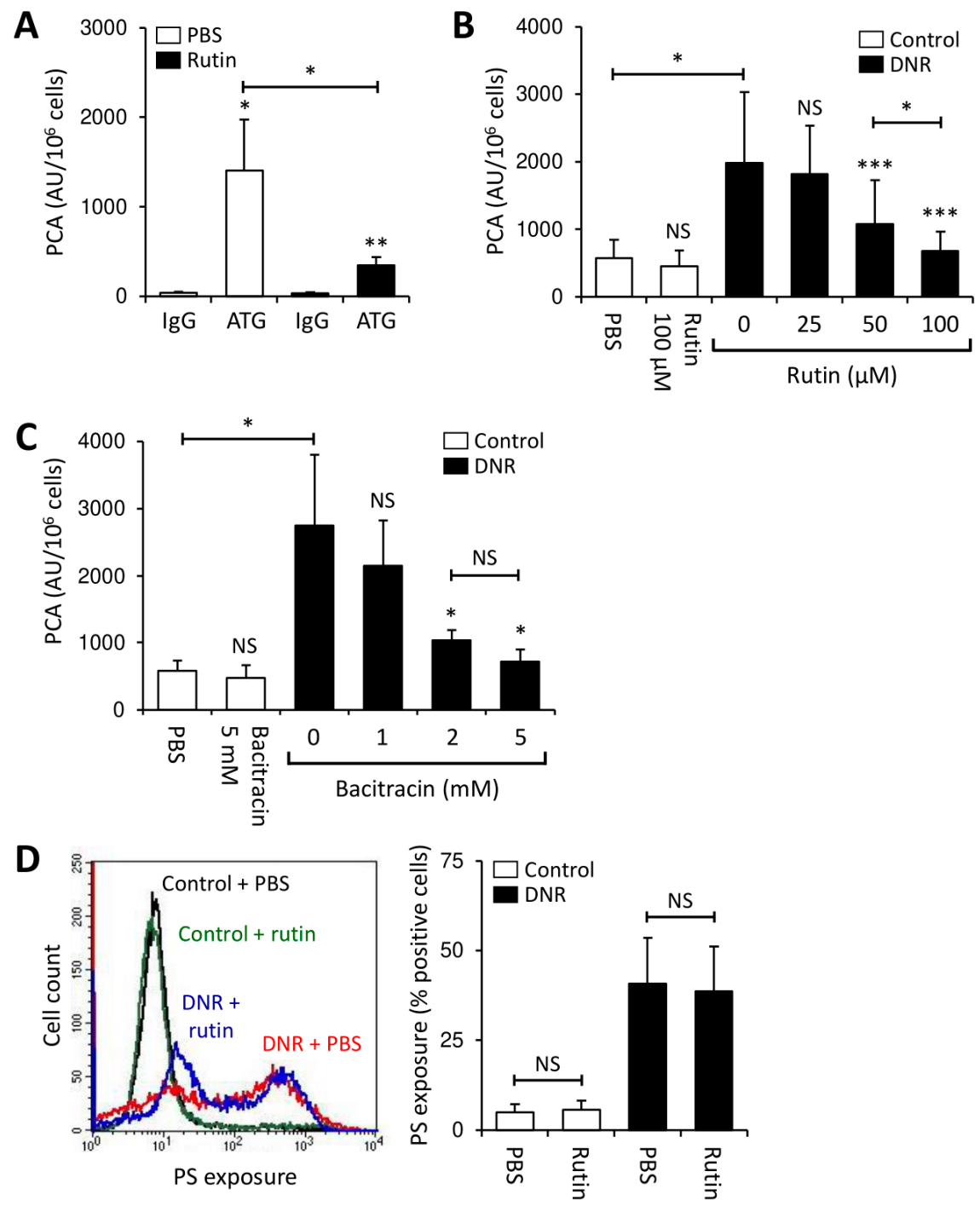

Figure 4. Rutin and bacitracin prevent activation of cryptic TF on THP1 cells. (A) THP1 cells were incubated with PBS or rutin $(100 \mu \mathrm{M})$ for $24 \mathrm{~h}$ at $37^{\circ} \mathrm{C}$, washed and subsequently loaded with $100 \mu \mathrm{g} / \mathrm{mL}$ ATG or rabbit IgG for $15 \mathrm{~min}$ at room temperature. Cells were washed and mixed 1:1 (vol:vol) with normal human plasma (NHP). Following incubation for 5 min at $37^{\circ} \mathrm{C}$, cellular PCA was analyzed by single-stage clotting assay (mean $\left.\pm \mathrm{SD}, n=6\right)$. (B,C) Following incubation of THP1 cells with $1 \mu \mathrm{M}$ daunorubicin (DNR) for $24 \mathrm{~h}$ at $37^{\circ} \mathrm{C}$ in the presence of increasing concentrations of rutin $(0-100 \mu \mathrm{M})(\mathrm{mean}$ $\pm \mathrm{SD}, n=15)(\mathbf{B})$ or bacitracin $(0-5 \mathrm{mM})$ (mean $\pm \mathrm{SD}, n=6)(C)$, cells were analyzed for PCA by single-stage clotting assay. (D) PS exposure on THP1 cells treated with PBS (control) or $1 \mu \mathrm{M}$ DNR in the presence or absence of $100 \mu \mathrm{M}$ rutin was measured by flow cytometry. A representative histogram and summary statistics are shown (mean $\pm \mathrm{SD}, n=3$ ). $p$-values are according to Tukey's post-hoc test (NS, not significant; ${ }^{*}, p<0.05 ;{ }^{* *}, p<0.01 ;{ }^{* * *}, p<0.001$ ). 


\subsection{Rutin Exerts Antithrombotic Activity in Myeloblasts from AML Patients}

To further explore the clinical implications of our findings obtained with monocytes and leukemic cell lines, we performed experiments using PBMCs isolated from a patient with newly diagnosed AML (patient 1 in Table S1). While intact PBMCs showed limited TF-dependent PCA, physical disruption by repeated freeze-thawing increased cellular TF PCA 6-fold (Figure 5A), indicating the presence of significant amounts of cryptic TF on the cell surface. In addition, substantial insulin reductase activity was expressed by PBMCs, which was completely blocked by rutin or bacitracin (Figure 5B). Overnight incubation with thiol isomerase inhibitors alone had no effect on cellular PCA but prevented cellular TF activation by ATG (Figure 5C) or DNR (Figure 5D). Prevention of DNR-induced TF activation by rutin was concentration-dependent (Figure 5E) and could not be explained by inhibition of apoptosis/necrosis (Figure 5F). Similar findings were obtained in two other patients with AML (patients 2 and 3 in Table S1). In both patients, co-incubation with rutin for $24 \mathrm{~h}$ alone did not affect the PCA of buffer-treated cells, but mitigated DNR-induced TF activation (Figure 6).

Collectively, these findings point to a central role of extracellular thiol isomerases, including PDI, in regulating myeloblast TF PCA in AML.
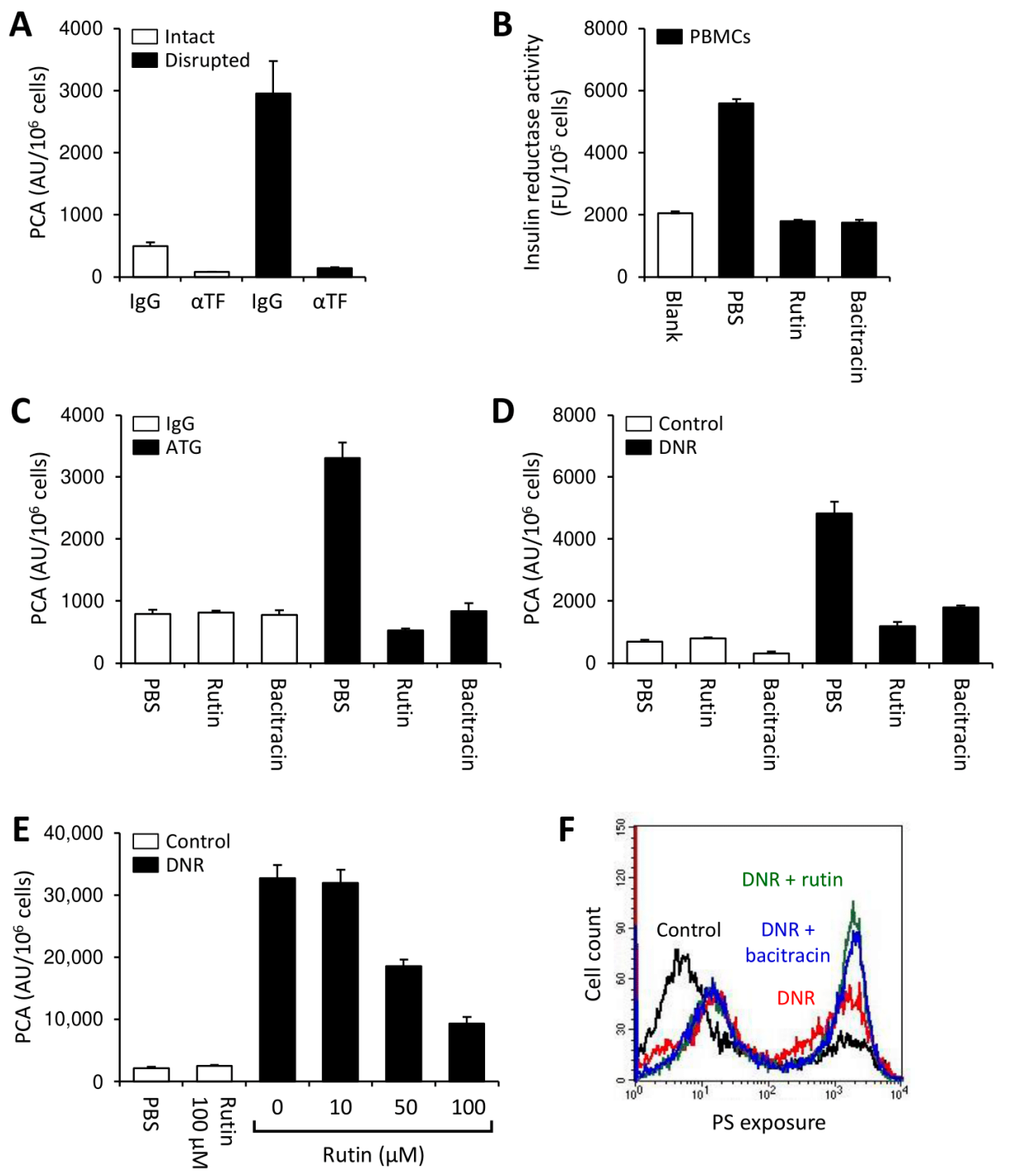

Figure 5. Activation of cryptic TF on PBMCs from a patient with acute myeloid leukemia (AML) is prevented by rutin and bacitracin. Whole-blood PBMCs were isolated from a patient with newly diagnosed AML and analyzed for PCA both before and after repeated freeze-thawing (A) and for insulin reductase activity in the presence or absence of $100 \mu \mathrm{M}$ rutin or 
$5 \mathrm{mM}$ bacitracin (B). (C) Following incubation with rutin $(100 \mu \mathrm{M})$ or bacitracin $(5 \mathrm{mM})$ for $24 \mathrm{~h}$ at $37^{\circ} \mathrm{C}$, ATG-mediated TF activation was measured as described before. (D) PBMCs were incubated with $1 \mu \mathrm{M}$ DNR in the presence of $100 \mu \mathrm{M}$ rutin or $5 \mathrm{mM}$ bacitracin for $24 \mathrm{~h}$ at $37^{\circ} \mathrm{C}$ before cell-associated PCA was measured by single-stage clotting assay. (E) Concentration dependency of the effect of rutin on DNR-mediated cellular TF activation. (F) Flow cytometric analysis of PS exposure on control and DNR-treated PBMCs co-incubated with rutin $(100 \mu \mathrm{M})$ or bacitracin $(5 \mu \mathrm{M})$. Results are presented as mean \pm SD of triplicate measurements.
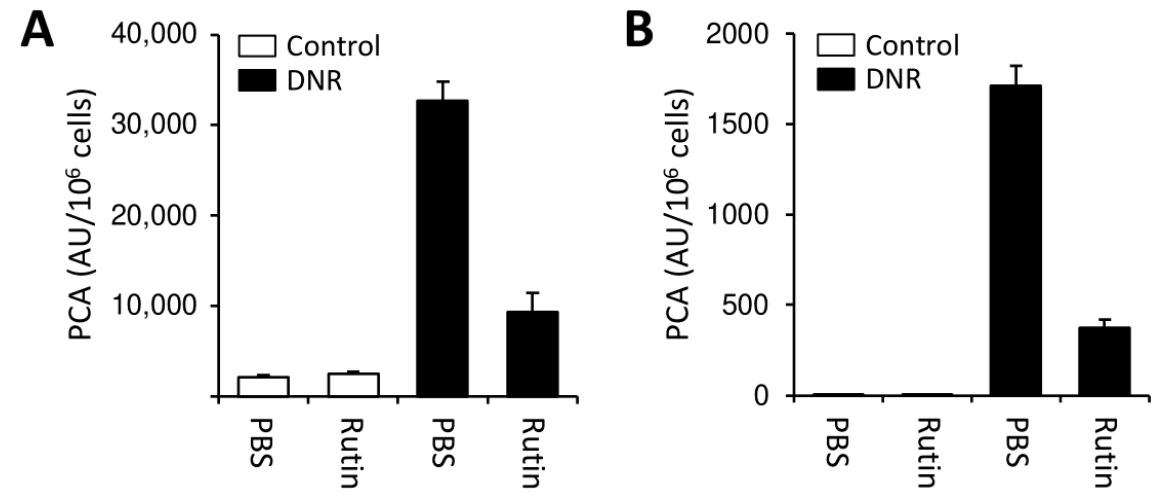

Figure 6. Effect of rutin on DNR-induced TF activation in PBMCs from AML patients. (A,B) Wholeblood PBMCs were isolated from two patients with newly diagnosed AML and incubated with $1 \mu \mathrm{M}$ DNR in the presence or absence of $100 \mu \mathrm{M}$ rutin for $24 \mathrm{~h}$ at $37^{\circ} \mathrm{C}$. Cells were washed and analyzed for PCA by single-stage clotting assay. Results are presented as mean \pm SD of triplicate measurements.

\section{Discussion}

In this study, we delineate a novel mechanism, by which thiol isomerases such as PDI regulate TF PCA in inflammatory monocytes and AML blasts. Thiol isomerase inhibition with rutin or bacitracin prevented LPS-mediated TF production by monocytes and downregulated constitutive TF expression by monocytic leukemia THP1 cells and PBMCs isolated from patients with newly diagnosed AML. Reduced de novo TF production was associated with decreased TF mRNA expression in LPS-treated monocytes and was mainly restricted to the cryptic pool of TF in THP1 cells and isolated myeloblasts, preventing its subsequent activation by ATG or DNR. Thus, PDI and other thiol isomerases might be promising new targets to prevent or treat TF-driven coagulation abnormalities in AML.

In initial experiments, we investigated the effect of thiol isomerases on TF induction in healthy monocytes (Figures 1 and 2). Co-incubation of monocytes with LPS and bacitracin or rutin mitigated de novo TF production, although the inhibitory effect of rutin was less pronounced compared to that of bacitracin (Figures 1 and 2). This discrepancy is likely explained by increased specificity of rutin for PDI over other vascular thiol isomerases, which also participate in thrombus formation, such as ERp5, ERp57, ERp72 or thioredoxin, while bacitracin is a more non-specific thiol isomerase inhibitor $[28,31-33,46,50]$. Of note, residual insulin reductase activity was detectable on PBMCs despite addition of $5 \mathrm{mM}$ bacitracin (Figure 1B), a concentration at least 10-fold exceeding the $\mathrm{IC}_{50}$ of bacitracin under our experimental conditions (Figure S1), which further points to a potential contribution of other thiol isomerases in the regulation of cellular TF PCA.

Previous studies have shown that PDI and other thiol isomerases regulate cellular TF activity by posttranslational modifications of free cysteine thiols or mixed disulfides within the TF extracellular domain, a mechanism independent of de novo TF production $[25,51-53]$. Disulfide bond formation between Cys186 and Cys209 was associated with the activation of cryptic TF to its procoagulant isoform independently of PS membrane exposure [25,51-54], and TF mutants lacking these cysteine residues were significantly less potent to promote coagulation [53,55]. Alternatively, PDI might serve as an activating chaperone to enhance TF PCA; bovine liver-derived PDI enhanced Xa generation induced by both soluble and MV-associated TF independently of thiol-disulfide exchange within Cys186-Cys209, an effect that could be completely abolished by bacitracin [51]. In addition, we have previously 
shown that ATG can rapidly activate monocyte TF in a PDI- and complement-dependent manner and that release of TF PCA into plasma upon stimulation of whole blood with LPS is mediated by PDI $[26,44]$. In the latter study, co-stimulation of whole blood with LPS and a function blocking C5 antibody did not interfere with TF antigen expression on CD14-positive monocytes, but largely prevented the release of TF PCA into plasma. Since LPS-induced TF PCA release was also inhibited by rutin, these findings pointed to synergistic roles of complement and PDI in the endotoxemia model, similar to those involved in ATG-mediated monocyte TF activation.

Our current study delineates that contribution of PDI to LPS-induced production of monocyte TF PCA is more complex, since thiol isomerases are also involved in the regulation of TF protein synthesis in myeloid cells. This finding is also supported by a recent study showing that LPS-stimulated bone marrow mononuclear cells from PDIdeficient compared to wildtype mice induced significantly less TF-dependent thrombin generation [30]. Although we cannot entirely rule out the possibility that interference with thiol-disulfide exchange reactions contributed to the inhibitory effects of rutin on LPSinduced monocyte TF PCA, the overall contribution of this effect appeared to be limited, since the time-dependency analysis revealed parallel reduction of TF PCA and TF antigen under our experimental conditions (Figure S4C). Moreover, reduction of the TF antigen was mainly restricted to its cryptic pool in monocytes (Figure 1C and Figure S4A) and THP1 cells (Figure S7D), because cellular PCA of unstimulated controls was not affected.

Although the precise mechanism by which thiol isomerases such as PDI regulate TF production remains elusive, LPS-induced PS exposure on CD14-positive monocytes and THP1 cells was not further amplified by thiol isomerase inhibitors (Figure 4D, Figures S2B and S4D), which makes decreased cell viability as the underlying mechanism highly unlikely. Interestingly, several studies have reported anti-inflammatory properties for flavonoids, such as rutin, by interfering with NFKB transcriptional activity with an $\mathrm{IC}_{50}$ of less than $39.5 \mu \mathrm{M}$ in vitro [56-58]. NFKB is implicated in the regulation of TF gene transcription [59] and critically involved in the LPS- and PAR2-mediated signaling pathways, with the latter being initiated by TF/FVIIa and TF/FVIIa/FXa complex formation $[11,53,60,61]$. Moreover, its transcriptional activity has been suggested to be under direct oxidoreductive control of PDI [62]. Thus, it remains tempting to speculate that thiol isomerases are involved in the regulation of TF production by an altered signal transduction, particularly by modification of NFKB transcriptional activity. However, this issue warrants further investigations.

Interestingly, MV-associated Xa generation was more efficiently reduced by rutin than cellular PCA in LPS-stimulated PBMCs, suggesting that rutin not only interfered with the supply of cryptic TF but also strongly attenuated shedding of TF-bearing MVs. Cell-injury signals such as LPS induce cellular ATP release [63], and ATP-triggered inflammatory signaling through the myelomonocytic P2X7 receptor enables shedding of procoagulant MVs into the extracellular space [64]. PDI-mediated thiol-disulfide exchange reactions within the $\mathrm{P} 2 \mathrm{X} 7$ receptor signaling pathway are required to incorporate TF into MVs [45,64-66]. Accordingly, reduction of MV-associated Xa generation by rutin might additionally be explained by impaired trafficking of TF onto MVs next to reduced TF production.

PDI is upregulated in several types of cancer, including kidney, ovarian, prostate, lung, brain and germ-cell tumors, as well as lymphoma, and inhibition of its reductase activity by rutin has been associated with promising anticancer activity in vitro and in vivo $[67,68]$. Several mechanisms for its anti-cancer activity have been identified, including inhibition of malignant cell growth, induction of cell cycle arrest and apoptosis and modulation of angiogenesis, inflammation and oxidative stress [68]. In addition, rutin has already been demonstrated, in some earlier studies, to interfere with proliferation of murine leukemia WEHI- 3 cells and of human HL-60 cells in a murine xenograft model, but the underlying mechanisms remained obscure [69,70]. In a recent study, PDI inhibition with SK053 initiated cell differentiation into mature myeloid cells in various AML cell lines and in blasts from six 
AML patients ex vivo [71]. Moreover, PDI has been shown to block myeloid differentiation by binding to the stem loop region of the C/EBP- $\alpha$ mRNA and calreticulin [36]. It is thus tempting to speculate that reduced TF production by THP1 cells might be explained by a cell differentiation process with consecutive loss of aberrant TF gene transcription. This could also explain why PS levels were similar to those of respective controls.

In our study, we analyzed PBMCs from three different AML patients, two of whom had a monocytic phenotype (Table S1). None of these patients developed clinically relevant bleeding or thrombotic complications during treatment. In all patients, overnight incubation with rutin prevented DNR-mediated TF activation ex vivo (Figures 5D and 6), suggesting a common thiol isomerase-mediated mechanism of myeloblast TF PCA regulation with potential therapeutic implications. Coagulation disorders in AML are complex. Although aberrant TF expression is not restricted to specific AML subtypes $[8,15,17]$, we and others showed that further mechanisms next to TF expression by PBMCs and shedding of TF-bearing MVs contribute to systemic coagulation activation in AML, including acquired activated protein C resistance and release of neutrophil extracellular traps (NETs) $[8,17,72-74]$. Whether inhibition of thiol isomerases interferes with these TF-independent mechanisms has yet to be established.

A significant shortcoming of our study is that off-target effects of bacitracin and rutin other than PDI inhibition might have suppressed TF production in our experiments. The non-specific PDI inhibitor bacitracin decreases the reductase activity of PDI by competitive binding to its substrate binding $b^{\prime}$ domain. It additionally inhibits various other enzymes required for protein folding, as well as cysteine proteases [75]. Rutin has higher specificity for PDI than bacitracin, but this flavonoid also targets other thiol isomerases, such as ERp5, ERp57, thioredoxin and thioredoxin reductase [67]. Although experiments using the inhibitory monoclonal antibody RL90 support a role of extracellular PDI in the regulation of TF production in THP1 cells (Figure S8A), downregulation of cellular PDI expression or use of newer-generation PDI inhibitors with higher potency and specificity would be necessary to better differentiate between PDI and other thiol isomerases [76].

Our study has several additional limitations. First, we isolated PBMCs from only three AML patients, which reduces the generalizability of our findings. Second, we analyzed PBMCs instead of pure myeloblasts. Thus, we cannot rule out the possibility that obtained results were confounded by contaminating monocytes. Third, none of our patients had suffered from bleeding or thromboembolic complications, which questions the clinical relevance of our ex vivo experiments. Finally, we cannot comment on the pathophysiological implications of our findings for patients with APL, which is characterized by a particularly severe coagulopathy and in which TF production is under direct control of the PML/RAR-alpha fusion protein. Hence, further studies are needed to confirm and extend our observations in a larger patient cohort. Still, administration of isoquercetin, a rutin derivative with high oral bioavailability, was safe and showed promising antithrombotic activity in healthy subjects as well as in patients with advanced solid cancers [34,35], which makes it a promising candidate for future clinical investigations.

\section{Conclusions}

Our study delineates a novel mechanism, by which thiol isomerases regulate cellular TF PCA. By preventing aberrant TF production by AML blasts and inflammatory monocytes, inhibition of PDI and other thiol isomerases may thus be a promising therapeutic approach in the management of AML-associated coagulation disorders.

Supplementary Materials: The following are available online at https:/ / www.mdpi.com/article/10 .3390 / cancers13163941/s1, Figure S1: Bacitracin dose-dependently inhibits PDI insulin reductase activity, Figure S2: Co-incubation with bacitracin dose-dependently inhibits LPS-induced TF PCA in PBMCs, but has no effect on PS membrane exposure, Figure S3: Rutin inhibits PDI insulin reductase activity in a concentration-dependent manner, Figure S4: Rutin inhibits LPS-induced TF production in PBMCs in a time- and concentration-dependent manner, Figure S5: Rutin inhibits LPS-induced TF production by PBMCs in whole blood, Figure S6: Short-time incubation with rutin reversibly inhibits 
insulin reductase activity of THP1 cells, Figure S7: TF is predominantly cryptic on intact THP1 cells, Figure S8: PDI inhibition on THP1 cells prevents activation of cryptic TF, Table S1: Demographic and clinico-pathological patient characteristics.

Author Contributions: L.B., C.C.R. and F.L. designed the study, analyzed data and wrote the first draft of the manuscript; M.V., J.M., F.K., A.S., C.L., C.B. and W.R. analyzed data and critically revised the manuscript. All authors have read and agreed to the published version of the manuscript.

Funding: This research received no external funding.

Institutional Review Board Statement: The study was conducted according to the guidelines of the Declaration of Helsinki. AML patients provided written informed consent within the framework of two prospective studies conducted at our institution, the protocols of which had been approved by the ethics committee of the city of Hamburg, Germany (no. OB-059/05 and PV5365). Healthy donors were recruited from hospital and laboratory staff following informed consent, according to the institutional statutory requirements.

Informed Consent Statement: Informed consent was obtained from all subjects involved in the study.

Data Availability Statement: The data presented in this study are available in "Bacitracin and rutin regulate tissue factor production in inflammatory monocytes and acute myeloid leukemia blasts" or in the supplementary appendix of the same article. Original data are available on request by the corresponding author.

Conflicts of Interest: The authors declare no conflict of interest.

\section{References}

1. Kwaan, H.C. Double Hazard of Thrombophilia and Bleeding in Leukemia. Hematol. Am. Soc. Hematol. Educ. Program 2007, 2007, 151-157. [CrossRef] [PubMed]

2. Kwaan, H.C.; Cull, E.H. The coagulopathy in acute promyelocytic leukaemia-What have we learned in the past twenty years. Best Pr. Res. Clin. Haematol. 2014, 27, 11-18. [CrossRef] [PubMed]

3. Webert, K.; Cook, R.J.; Sigouin, C.S.; Rebulla, P.; Heddle, N.M. The risk of bleeding in thrombocytopenic patients with acute myeloid leukemia. Haematologica 2006, 91, 1530-1537. [CrossRef]

4. Wu, Y.-Y.; Tang, L.; Wang, M.-H. Leukemia and Risk of Venous Thromboembolism: A Meta-analysis and Systematic Review of 144 Studies Comprising 162,126 Patients. Sci. Rep. 2017, 7, 1167. [CrossRef] [PubMed]

5. Mohren, M.; Markmann, I.; Jentsch-Ullrich, K.; Koenigsmann, M.; Lutze, G.; Franke, A. Increased risk of venous thromboembolism in patients with acute leukaemia. Br. J. Cancer 2006, 94, 200-202. [CrossRef]

6. Libourel, E.J.; Klerk, C.P.W.; Van Norden, Y.; De Maat, M.P.M.; Kruip, M.J.; Sonneveld, P.; Löwenberg, B.; Leebeek, F.W.G. Disseminated intravascular coagulation at diagnosis is a strong predictor for thrombosis in acute myeloid leukemia. Blood 2016, 128, 1854-1861. [CrossRef]

7. Vu, K.; Luong, N.V.; Hubbard, J.; Zalpour, A.; Faderl, S.; Thomas, D.A.; Yang, D.; Kantarjian, H.; Kroll, M.H. A retrospective study of venous thromboembolism in acute leukemia patients treated at the University of Texas MD Anderson Cancer Center. Cancer Med. 2015, 4, 27-35. [CrossRef]

8. Dicke, C.; Amirkhosravi, A.; Spath, B.; Jiménez-Alcázar, M.; Fuchs, T.; Davila, M.; Francis, J.L.; Bokemeyer, C.; Langer, F. Tissue factor-dependent and -independent pathways of systemic coagulation activation in acute myeloid leukemia: A single-center cohort study. Exp. Hematol. Oncol. 2015, 4, 22. [CrossRef]

9. Breen, K.A.; Grimwade, D.; Hunt, B.J. The pathogenesis and management of the coagulopathy of acute promyelocytic leukaemia. Br. J. Haematol. 2012, 156, 24-36. [CrossRef]

10. Grover, S.P.; Mackman, N. Tissue Factor: An Essential Mediator of hemostasis and Trigger of Thrombosis. Arter. Thromb. Vasc. Biol. 2018, 38, 709-725. [CrossRef] [PubMed]

11. Zelaya, H.; Rothmeier, A.S.; Ruf, W. Tissue factor at the crossroad of coagulation and cell signaling. J. Thromb. Haemost. 2018, 16, 1941-1952. [CrossRef] [PubMed]

12. Ebert, J.; Wilgenbus, P.; Teiber, J.F.; Jurk, K.; Schwierczek, K.; Döhrmann, M.; Xia, N.; Li, H.; Spiecker, L.; Ruf, W.; et al. Paraoxonase-2 regulates coagulation activation through endothelial tissue factor. Blood 2018, 131, 2161-2172. [CrossRef] [PubMed]

13. Hisada, Y.; Mackman, N. Tissue Factor and Cancer: Regulation, Tumor Growth, and Metastasis. Semin. Thromb. Hemost. 2019, 45, 385-395. [CrossRef]

14. Han, X.; Guo, B.; Li, Y.; Zhu, B. Tissue factor in tumor microenvironment: A systematic review. J. Hematol. Oncol. 2014, 7, 54. [CrossRef] [PubMed]

15. Tanaka, M.; Yamanishi, H. The expression of tissue factor antigen and activity on the surface of leukemic cells. Leuk. Res. 1993, 17, 103-111. [CrossRef]

16. Bauer, K.A.; Conway, E.M.; Bach, R.; Konigsberg, W.H.; Griffin, J.D.; Demetri, G. Tissue factor gene expression in acute myeloblastic leukemia. Thromb. Res. 1989, 56, 425-430. [CrossRef] 
17. Nadir, Y.; Katz, T.; Sarig, G.; Hoffman, R.; Oliven, A.; Rowe, J.M.; Brenner, B. Hemostatic balance on the surface of leukemic cells: The role of tissue factor and urokinase plasminogen activator receptor. Haematologica 2005, 90, 1549-1556.

18. Craver, B.M.; El Alaoui, K.; Scherber, R.M.; Fleischman, A.G. The Critical Role of Inflammation in the Pathogenesis and Progression of Myeloid Malignancies. Cancers 2018, 10, 104. [CrossRef]

19. Langer, F.; Ruf, W. Synergies of phosphatidylserine and protein disulfide isomerase in tissue factor activation. Thromb. Haemost. 2014, 111, 590-597. [CrossRef]

20. Ansari, S.A.; Pendurthi, U.R.; Rao, L.V.M. Role of Cell Surface Lipids and Thiol-Disulphide Exchange Pathways in Regulating the Encryption and Decryption of Tissue Factor. Thromb. Haemost. 2019, 119, 860-870. [CrossRef]

21. Drake, T.A.; Ruf, W.; Morrissey, J.H.; Edgington, T.S. Functional tissue factor is entirely cell surface expressed on lipopolysaccharide-stimulated human blood monocytes and a constitutively tissue factor-producing neoplastic cell line. J. Cell Biol. 1989, 109, 389-395. [CrossRef] [PubMed]

22. Hatahet, F.; Ruddock, L.W. Protein disulfide isomerase: A critical evaluation of its function in disulfide bond formation. Antioxid. Redox Signal. 2009, 11, 2807-2850. [CrossRef] [PubMed]

23. Cho, J.; Kennedy, D.R.; Lin, L.; Huang, M.; Merrill-Skoloff, G.; Furie, B.C.; Furie, B. Protein disulfide isomerase capture during thrombus formation in vivo depends on the presence of $\beta 3$ integrins. Blood 2012, 120, 647-655. [CrossRef]

24. Jasuja, R.; Furie, B.; Furie, B.C. Endothelium-derived but not platelet-derived protein disulfide isomerase is required for thrombus formation in vivo. Blood 2010, 116, 4665-4674. [CrossRef] [PubMed]

25. Reinhardt, C.; Von Brühl, M.-L.; Manukyan, D.; Grahl, L.; Lorenz, M.; Altmann, B.; Dlugai, S.; Hess, S.; Konrad, I.; Orschiedt, L.; et al. Protein disulfide isomerase acts as an injury response signal that enhances fibrin generation via tissue factor activation. $J$. Clin. Investig. 2008, 118, 1110-1122. [CrossRef] [PubMed]

26. Subramaniam, S.; Jurk, K.; Hobohm, L.; Jäckel, S.; Saffarzadeh, M.; Schwierczek, K.; Wenzel, P.; Langer, F.; Reinhardt, C.; Ruf, W. Distinct contributions of complement factors to platelet activation and fibrin formation in venous thrombus development. Blood 2017, 129, 2291-2302. [CrossRef]

27. Cho, J.; Furie, B.C.; Coughlin, S.R.; Furie, B. A critical role for extracellular protein disulfide isomerase during thrombus formation in mice. J. Clin. Investig. 2008, 118, 1123-1131. [CrossRef]

28. Jasuja, R.; Passam, F.H.; Kennedy, D.R.; Kim, S.H.; Van Hessem, L.; Lin, L.; Bowley, S.R.; Joshi, S.S.; Dilks, J.R.; Furie, B.; et al. Protein disulfide isomerase inhibitors constitute a new class of antithrombotic agents. J. Clin. Investig. 2012, 122, $2104-2113$. [CrossRef]

29. Kim, K.; Hahm, E.; Li, J.; Holbrook, L.-M.; Sasikumar, P.; Stanley, R.G.; Ushio-Fukai, M.; Gibbins, J.M.; Cho, J. Platelet protein disulfide isomerase is required for thrombus formation but not for hemostasis in mice. Blood 2013, 122, 1052-1061. [CrossRef]

30. Chen, F.; Zhao, Z.; Zhou, J.; Lu, Y.; Essex, D.W.; Wu, Y. Protein disulfide isomerase enhances tissue factor-dependent thrombin generation. Biochem. Biophys. Res. Commun. 2018, 501, 172-177. [CrossRef]

31. Zhou, J.; Wu, Y.; Chen, F.; Wang, L.; Rauova, L.; Hayes, V.M.; Poncz, M.; Li, H.; Liu, T.; Liu, J.; et al. The disulfide isomerase ERp72 supports arterial thrombosis in mice. Blood 2017, 130, 817-828. [CrossRef]

32. Passam, F.H.; Lin, L.; Gopal, S.; Stopa, J.D.; Bellido-Martin, L.; Huang, M.; Furie, B.C.; Furie, B. Both platelet- and endothelial cell-derived ERp5 support thrombus formation in a laser-induced mouse model of thrombosis. Blood 2015, 125, 2276-2285. [CrossRef] [PubMed]

33. Wang, L.; Wu, Y.; Zhou, J.; Ahmad, S.S.; Mutus, B.; Garbi, N.; Hämmerling, G.; Liu, J.; Essex, D.W. Platelet-derived ERp57 mediates platelet incorporation into a growing thrombus by regulation of the $\alpha \operatorname{Ilb} \beta 3$ integrin. Blood 2013, 122, 3642-3650. [CrossRef]

34. Stopa, J.D.; Neuberg, D.; Puligandla, M.; Furie, B.; Flaumenhaft, R.; Zwicker, J.I. Protein disulfide isomerase inhibition blocks thrombin generation in humans by interfering with platelet factor $\mathrm{V}$ activation. JCI Insight 2017, 2, e89373. [CrossRef]

35. Zwicker, J.I.; Schlechter, B.L.; Stopa, J.D.; Liebman, H.A.; Aggarwal, A.; Puligandla, M.; Caughey, T.; Bauer, K.A.; Kuemmerle, N.; Wong, E.; et al. Targeting protein disulfide isomerase with the flavonoid isoquercetin to improve hypercoagulability in advanced cancer. JCI Insight 2019, 4. [CrossRef] [PubMed]

36. Haefliger, S.; Klebig, C.; Schaubitzer, K.; Schardt, J.; Timchenko, N.; Mueller, B.U.; Pabst, T. Protein disulfide isomerase blocks CEBPA translation and is up-regulated during the unfolded protein response in AML. Blood 2011, 117, 5931-5940. [CrossRef]

37. Holstein, K.; Matysiak, A.; Witt, L.; Sievers, B.; Beckmann, L.; Haddad, M.; Renné, T.; Voigtlaender, M.; Langer, F. LPS-induced expression and release of monocyte tissue factor in patients with haemophilia. Ann. Hematol. 2020, 99, 1531-1542. [CrossRef] [PubMed]

38. Lee, R.D.; Barcel, D.A.; Williams, J.C.; Wang, J.G.; Boles, J.C.; Manly, D.A.; Key, N.S.; Mackman, N. Pre-analytical and analytical variables affecting the measurement of plasma-derived microparticle tissue factor activity. Thromb. Res. 2012, 129, 80-85. [CrossRef]

39. Basavaraj, M.G.; Olsen, J.O.; Østerud, B.; Hansen, J.-B. Differential ability of tissue factor antibody clones on detection of tissue factor in blood cells and microparticles. Thromb. Res. 2012, 130, 538-546. [CrossRef]

40. Nieuwland, R.; Gardiner, C.; Dignat-George, F.; Mullier, F.; Mackman, N.; Woodhams, B.; Thaler, J. Toward standardization of assays measuring extracellular vesicle-associated tissue factor activity. J. Thromb. Haemost. 2019, 17, 1261-1264. [CrossRef]

41. Beckmann, L.; Dicke, C.; Spath, B.; Lehr, C.; Sievers, B.; Klinke, A.; Baldus, S.; Rudolph, V.; Langer, F. Myeloperoxidase Is a Negative Regulator of Phospholipid-Dependent Coagulation. Thromb. Haemost. 2017, 117, 2300-2311. [CrossRef] 
42. Jacobsen, C.; Oechsle, K.; Hauschild, J.; Steinemann, G.; Spath, B.; Bokemeyer, C.; Ruf, W.; Honecker, F.; Langer, F. Regulation of tissue factor in NT2 germ cell tumor cells by cisplatin chemotherapy. Thromb. Res. 2015, 136, 673-681. [CrossRef]

43. Pfaffl, M.W. A new mathematical model for relative quantification in real-time RT-PCR. Nucleic Acids Res. 2001, 29, e45. [CrossRef]

44. Langer, F.; Spath, B.; Fischer, C.; Stolz, M.; Ayuk, F.A.; Kröger, N.; Bokemeyer, C.; Ruf, W. Rapid activation of monocyte tissue factor by antithymocyte globulin is dependent on complement and protein disulfide isomerase. Blood 2013, 121, 2324-2335. [CrossRef]

45. Rothmeier, A.S.; Marchese, P.; Langer, F.; Kamikubo, Y.; Schaffner, F.; Cantor, J.; Ginsberg, M.H.; Ruggeri, Z.M.; Ruf, W. Tissue Factor Prothrombotic Activity Is Regulated by Integrin-arf6 Trafficking. Arter. Thromb. Vasc. Biol. 2017, 37, 1323-1331. [CrossRef] [PubMed]

46. Lin, L.; Gopal, S.; Sharda, A.; Passam, F.; Bowley, S.R.; Stopa, J.; Xue, G.; Yuan, C.; Furie, B.C.; Flaumenhaft, R.; et al. Quercetin-3rutinoside Inhibits Protein Disulfide Isomerase by Binding to Its b’x Domain. J. Biol. Chem. 2015, 290, 23543-23552. [CrossRef] [PubMed]

47. Kallakunta, V.M.; Slama-Schwok, A.; Mutus, B. Protein disulfide isomerase may facilitate the efflux of nitrite derived Snitrosothiols from red blood cells. Redox Biol. 2013, 1, 373-380. [CrossRef]

48. Voigtlaender, M.; Holstein, K.; Spath, B.; Bokemeyer, C.; Langer, F. Expression and release of platelet protein disulphide isomerase in patients with haemophilia A. Haemophilia 2016, 22, e537-e544. [CrossRef]

49. Langer, F.; Amirkhosravi, A.; Loges, S.; Meyer, T.; Eifrig, B.; Hossfeld, D.K.; Fiedler, W.; Francis, J.L. An in vitro study on the mechanisms of coagulation activation in acute myelogenous leukemia (AML): Role of tissue factor regulation by cytotoxic drugs and GM-CSF. Thromb. Haemost. 2004, 92, 1136-1146. [CrossRef]

50. Bekendam, R.H.; Bendapudi, P.K.; Lin, L.; Nag, P.P.; Pu, J.; Kennedy, D.R.; Feldenzer, A.; Chiu, J.; Cook, K.M.; Furie, B.; et al. A substrate-driven allosteric switch that enhances PDI catalytic activity. Nat. Commun. 2016, 7, 12579. [CrossRef]

51. Versteeg, H.H.; Ruf, W. Tissue factor coagulant function is enhanced by protein-disulfide isomerase independent of oxidoreductase activity. J. Biol. Chem. 2007, 282, 25416-25424. [CrossRef] [PubMed]

52. Hengel, L.G.V.D.; Osanto, S.; Reitsma, P.H.; Versteeg, H.H. Murine tissue factor coagulant activity is critically dependent on the presence of an intact allosteric disulfide. Haematologica 2013, 98, 153-158. [CrossRef] [PubMed]

53. Ahamed, J.; Versteeg, H.H.; Kerver, M.; Chen, V.M.; Mueller, B.M.; Hogg, P.J.; Ruf, W. Disulfide isomerization switches tissue factor from coagulation to cell signaling. Proc. Natl. Acad. Sci. USA 2006, 103, 13932-13937. [CrossRef] [PubMed]

54. Chen, V.M.; Ahamed, J.; Versteeg, H.H.; Berndt, M.C.; Ruf, W.; Hogg, P.J. Evidence for activation of tissue factor by an allosteric disulfide bond. Biochemistry 2006, 45, 12020-12028. [CrossRef] [PubMed]

55. Ruf, W.; Versteeg, H.H. Tissue factor mutated at the allosteric Cys186-Cys209 disulfide bond is severely impaired in decrypted procoagulant activity. Blood 2010, 116, 500-501. [CrossRef] [PubMed]

56. Muraoka, K.; Shimizu, K.; Sun, X.; Tani, T.; Izumi, R.; Miwa, K.; Yamamoto, K. Flavonoids exert diverse inhibitory effects on the activation of NF-kappaB. Transplant. Proc. 2002, 34, 1335-1340. [CrossRef]

57. Endringer, D.C.; Pezzuto, J.M.; Braga, F.C. NF-kappaB inhibitory activity of cyclitols isolated from hancornia speciosa. Phytomedicine 2009, 16, 1064-1069. [CrossRef]

58. Siriwatanametanon, N.; Heinrich, M. The Thai Medicinal Plant Gynura Pseudochina var. hispida: Chemical Composition and in vitro NF-кB Inhibitory Activity. Nat. Prod. Commun. 2011, 6, 1934578X1100600512. [CrossRef]

59. Bode, M.; Mackman, N. Regulation of tissue factor gene expression in monocytes and endothelial cells: Thromboxane A2 as a new player. Vasc. Pharmacol. 2014, 62, 57-62. [CrossRef] [PubMed]

60. Rothmeier, A.S.; Ruf, W. Protease-activated receptor 2 signaling in inflammation. Semin. Immunopathol. 2012, 34, 133-149. [CrossRef]

61. Lu, Y.-C.; Yeh, W.-C.; Ohashi, P.S. LPS/TLR4 signal transduction pathway. Cytokine 2008, 42, 145-151. [CrossRef]

62. Higuchi, T.; Watanabe, Y.; Waga, I. Protein disulfide isomerase suppresses the transcriptional activity of NF-kappaB. Biochem. Biophys. Res. Commun. 2004, 318, 46-52. [CrossRef] [PubMed]

63. Sperlágh, B.; Haskó, G.; Németh, Z.; Vizi, E.S. ATP released by LPS increases nitric oxide production in raw 264.7 macrophage cell line via P2Z/P2X7 receptors. Neurochem. Int. 1998, 33, 209-215. [CrossRef]

64. Furlan-Freguia, C.; Marchese, P.; Gruber, A.; Ruggeri, Z.M.; Ruf, W. P2X7 receptor signaling contributes to tissue factor-dependent thrombosis in mice. J. Clin. Investig. 2011, 121, 2932-2944. [CrossRef]

65. Ansari, S.A.; Pendurthi, U.R.; Rao, L.V.M. The lipid peroxidation product 4-hydroxy-2-nonenal induces tissue factor decryption via ROS generation and the thioredoxin system. Blood Adv. 2017, 1, 2399-2413. [CrossRef]

66. Rothmeier, A.S.; Marchese, P.; Petrich, B.G.; Furlan-Freguia, C.; Ginsberg, M.H.; Ruggeri, Z.M.; Ruf, W. Caspase-1-mediated pathway promotes generation of thromboinflammatory microparticles. J. Clin. Investig. 2015, 125, 1471-1484. [CrossRef]

67. Xu, S.; Sankar, S.; Neamati, N. Protein disulfide isomerase: A promising target for cancer therapy. Drug Discov. Today 2014, 19, 222-240. [CrossRef] [PubMed]

68. Nouri, Z.; Fakhri, S.; Nouri, K.; Wallace, C.E.; Farzaei, M.H.; Bishayee, A. Targeting Multiple Signaling Pathways in Cancer: The Rutin Therapeutic Approach. Cancers 2020, 12, 2276. [CrossRef] [PubMed]

69. Lin, J.-P.; Yang, J.-S.; Lu, C.-C.; Chiang, J.-H.; Wu, C.-L.; Lin, J.-J.; Lin, H.-L.; Yang, M.-D.; Liu, K.-C.; Chiu, T.-H.; et al. Rutin inhibits the proliferation of murine leukemia WEHI-3 cells in vivo and promotes immune response in vivo. Leuk. Res. 2009, 33, 823-828. [CrossRef] [PubMed] 
70. Lin, J.-P.; Yang, J.-S.; Lin, J.-J.; Lai, K.-C.; Lu, H.-F.; Ma, C.-Y.; Sai-Chuen Wu, R.; Wu, K.-C.; Chueh, F.-S.; Gibson Wood, W.; et al. Rutin inhibits human leukemia tumor growth in a murine xenograft model in vivo. Environ. Toxicol. 2012, 27, 480-484. [CrossRef] [PubMed]

71. Chlebowska-Tuz, J.; Sokolowska, O.; Gaj, P.; Lazniewski, M.; Firczuk, M.; Borowiec, K.; Sas-Nowosielska, H.; Bajor, M.; Malinowska, A.; Muchowicz, A.; et al. Inhibition of protein disulfide isomerase induces differentiation of acute myeloid leukemia cells. Haematologica 2018, 103, 1843-1852. [CrossRef]

72. Negaard, H.F.S.; Iversen, P.O.; Ostenstad, B.; Mowinckel, M.C.; Sandset, P.M. Increased acquired activated protein C resistance in unselected patients with hematological malignancies. J. Thromb. Haemost. 2008, 6, 1482-1487. [CrossRef] [PubMed]

73. Negaard, H.F.S.; Iversen, P.O.; Østenstad, B.; Iversen, N.; Holme, P.A.; Sandset, P.M. Hypercoagulability in patients with haematological neoplasia: No apparent initiation by tissue factor. Thromb. Haemost. 2008, 99, 1040-1048. [CrossRef]

74. Tripodo, C.; Burocchi, A.; Piccaluga, P.P.; Chiodoni, C.; Portararo, P.; Cappetti, B.; Botti, L.; Gulino, A.; Isidori, A.; Liso, A.; et al. Persistent Immune Stimulation Exacerbates Genetically Driven Myeloproliferative Disorders via Stromal Remodeling. Cancer Res. 2017, 77, 3685-3699. [CrossRef] [PubMed]

75. Karala, A.-R.; Ruddock, L.W. Bacitracin is not a specific inhibitor of protein disulfide isomerase. FEBS J. 2010, $277,2454-2462$. [CrossRef] [PubMed]

76. Powell, L.E.; Foster, P.A. Protein disulphide isomerase inhibition as a potential cancer therapeutic strategy. Cancer Med. 2021, 10, 2812-2825. [CrossRef] 